\title{
Territorial dynamics of an urban state park in Pará-Brazil
}

\author{
Dinâmica territorial de um parque estadual urbano no Pará- Brasill \\ Dinámica territorial de un parque estatal urbano en Pará-Brasil
}

Received: 04/25/2021 | Reviewed: 05/03/2021 | Accept: 07/18/2021 | Published: 07/26/2021

Charles Benedito Gemaque Souza

ORCID: https://orcid.org/0000-0002-5966-9556

Secretaria de Estado de Meio Ambiente e Sustentabilidade, Brazil E-mail: charles@gmail.com

Francimary da Silva Carneiro

ORCID: https://orcid.org/0000-0002-1693-8779

Secretaria de Estado de Meio Ambiente e Sustentabilidade, Brazil

E-mail: francimarycarneiro@gmail.com

Glayson Francisco Bezerra das Chagas

ORCID: https://orcid.org/0000-0002-5796-1924

Secretaria de Estado de Meio Ambiente e Sustentabilidade, Brazil

E-mail: chagasmeteorologista@gmail.com

Ana Marcela Alves dos Santos

ORCID: https://orcid.org/0000-0002-9498-8587

Secretaria de Estado de Meio Ambiente e Sustentabilidade, Brazi

E-mail: anamarcela-santos@ hotmail.com

Monique Bezerra Nascimento

ORCID: https://orcid.org/0000-0002-7744-2400

Secretaria de Estado de Meio Ambiente e Sustentabilidade, Brazil

E-mail: moniqueb.nascimento@ hotmail.com

Carla Vanessa Borges Castro

ORCID: https://orcid.org/0000-0002-5066-0862

Secretaria de Estado de Meio Ambiente e Sustentabilidade, Brazi

E-mail: carlavbcastro@yahoo.com.br

Paula Magno do Amaral

ORCID: https://orcid.org/0000-0002-1749-791X

Secretaria de Estado de Meio Ambiente e Sustentabilidade, Brazil

E-mail: magno_ana@yahoo.com.br

Lilian Conceição Tavares

ORCID: https://orcid.org/0000-0003-0071-2932

Secretaria de Estado de Meio Ambiente e Sustentabilidade, Brazil

E-mail: lilianc.tavares@hotmail.com

Klewton Adriano Oliveira Pinheiro

ORCID: https://orcid.org/0000-0003-2696-4249

Instituto Federal de Educação, Ciência e Tecnologia do Pará, Brazil

E-mail: klewton.pinheiro@gmail.com

\begin{abstract}
The Utinga State Park (PEUt) is one of the few green areas with the function of preserving the biodiversity remaining in the urbanization process of the Belém area. Add to this the fact that the effectiveness of the use control is directly linked to maintaining the quality of the city's water supply. In this context, the idea of environmental protection involves different perspectives, which are directly linked to territorial challenges in view of the patterns of development of the metropolitan form in the Amazon.
\end{abstract}

Keywords: Urban park; Biodiversity; Urbanization; Territorial; Amazon.

\section{Resumo}

O Parque Estadual do Utinga (PEUt) é uma das poucas áreas verdes com a função de preservar a biodiversidade remanescente no processo de urbanização da área de Belém. Some-se a isso o fato de que a eficácia do controle do uso está diretamente ligada à manutenção da qualidade do abastecimento de água da cidade. Nesse contexto, a ideia de proteção ambiental envolve diferentes perspectivas, as quais estão diretamente ligadas aos desafios territoriais tendo em vista os padrões de desenvolvimento da forma metropolitana na Amazônia.

Palavras-chave: Parque urbano; Biodiversidade; Urbanização; Territorial; Amazônia..

\section{Resumen}

El Parque Estatal de Utinga (PEUt) es una de las pocas áreas verdes con la función de preservar la biodiversidad que queda en el proceso de urbanización del área de Belém. A esto se suma el hecho de que la efectividad del control de 
uso está directamente relacionada con el mantenimiento de la calidad del suministro de agua de la ciudad. En este contexto, la idea de protección ambiental involucra diferentes perspectivas, las cuales están directamente ligadas a los desafíos territoriales en vista de los patrones de desarrollo de la forma metropolitana en la Amazonía.

Palabras clave: Parque urbano; Biodiversidad; Urbanización; Territorial; Amazonia.

\section{Introduction}

The Utinga State Park (PEUT) is one of the few green areas with the function of preserving biodiversity remaining in the urbanization process of the Belém space. Added to this is the fact that the effectiveness of controlling the use of the park is directly linked to the maintenance of the quality of the supply water, since it houses the so-called "water granary" of the city.

In this context, its environmental management involves different views, which are directly linked to the challenges of sustainability in the face of the patterns of development of the metropolitan form. In general, the creation of a park in the urban area is coupled with the idea of preservation and quality of life through environmental services to society through the filtering of air, water, wind and noise pollution; stabilization of the local microclimate; formation of an environmental education and visitation space that positively influences mental and physical health, in addition to sheltering wild animals native or introduced to the area.

According to the SNUC (federal law 9,985 / 00), national parks are a specific type of Conservation Units (UCs) with full protection whose main objective is "to preserve the environment and the quality of life of the populations that live in the surroundings of these areas. "(Brasil, 2000). In its article 11, the federal law states that the purpose of creating a national park is mainly "the preservation of natural ecosystems of great ecological relevance and scenic beauty, enabling scientific research and the development of environmental education and recreation activities in contact with nature and ecological tourism ".

However, Castro Júnior et al (2009: 39) points out that in Brazil, unlike other countries, national parks were established primarily in areas with already established human activities, to protect the remaining ecosystems, which imposes a basic guideline from the beginning. for the management of the area: that of combating the impacts caused by the occupants of the area.

Thus, this category of UC in Brazil is already interspersed with territorial conflicts, which puts the implementation of political instruments as a priority in relation to environmental services and the preservation function. As a result, the location of urban parks in Brazil effectively encompasses ecological dimensions, as suggested by the SNUC, but, equally, social, economic and cultural interests, which implies primarily in disputes between the stakeholders involved.

As a result, the sustainability discourse is socially incorporated by the social actors and, at the same time, challenged in a mutable, contradictory and complex interaction according to the power relations at stake. The relevance of this perspective lies in the inclusion within the logic of ecological protection, the question of the uneven dynamics of the costs and benefits of cities associated with the creation of a "conservation territory" that necessarily involves the consolidation of environmental management.

On the other hand, the definitions and functionalities of these protected areas are transformed according to the interactions between public policies, the action of the surrounding population and the perception of managers about preservation. According to Cardoso et al (2015: 77) the meaning of an urban park is commonly reduced to green areas for leisure and visitation, distinguishing itself from squares and botanical gardens by the size of the area, influencing the territorial ordering.

In this respect,the importance of analyzing conflicts associated with public policies aimed at sustainability is fundamental for understanding the ways that social groups affect and are affected by the urban park and by the dynamism of the environment. The result of this research will represent an instrument to support the environmental management of protected areas of integral protection in the urban space in the Amazon. 
Therefore, it is essential to assess the extent to which the environmental park is fulfilling the objectives that guided its creation, at the same time, that it is necessary to point out which social agents are being effectively benefited by the consolidation of the "conservation territory". The fact is that the restrictions on land use and occupation that were imposed by the presence of a protected area in the middle of the expansion area of Belém, affected the dynamics of spontaneous occupation of the Utinga area.

\section{Methodology}

\section{The sustainability of Utinga's springs in view of the urbanization of Belém}

The process of occupation of the PEUT area is the result of the disorderly growth of the Metropolitan Region of Belém (RMB), the date of the construction of the Belém-Bragança Railway, in 1883, whose initial stretch was close to the Utinga hydrographic basin, where the main water supply sources of the city were.

The PEUT is inserted between the transition areas and urban expansion of the RMB. These, added to the central area, configure the three relatively distinct portions into which the urban area of Belém is divided. The central area is characterized by a past urbanization block, within the first heritage league, limited by the Guajará bay, by the Guamá river and the so-called Institutional Belt. In this area are the main centers of trade and services of the RMB, most of the urban equipment and the highest population density.

The area of transition or immediate expansion appears as a continuation of the growth process of Belém beyond the institutional areas, marking the beginning of the urban appropriation of the Second League towards the BR-316 and Augusto Montenegro highways, the main vectors of expansion of the city. The occupation takes place predominantly along the main roads, through the implementation of housing estates, spontaneous subdivisions and urban equipment, however the institutional areas allow the preservation of extensive land, in which the Utinga area is inserted.

The urban expansion area, located after the Institutional Belt, occurs along the main exit routes of the city -BR-316 and Augusto Montenegro - leaving extensive empty spaces between the occupied areas. The BR-316, connects Belém to Ananindeua and follows, in its initial stretch, the western and northern limits of the PEUT. The BR 316 highway is considered to be the main driver of metropolitan expansion, both because of the geophysical characteristics of areas favorable to occupation, and because of the lack of territorial continuity barriers for occupation.

Over the years, the intensification of rural urban migration has led to the densification and growth of the urban site of Belém, which together with the lack of public policies have introduced unsustainable situations in the city (Vieira and Pereira 2016, p. 732 ) for the Amazonian context. There is a great socio-spatial inequality in the city, in which urban services are more concentrated in the central area, prioritized primarily by the public administration, to the detriment of the existing needs in the areas of transition and expansion of the RMB.

In the early days of the city of Belém, water was obtained through spouts and wells located in public or private areas. According to Santos (2010, p.45) this type of supply lasted until the middle of the 19th century, through "downpours", people who sold water on the streets. According to Bordalo (2006), in 1839 there were 10 public wells, although of a lower quality than private wells, and several attempts were made to improve the use of water. In 1855, the metallic reservoir of São Brás started to operate, which received pumped water from an underground reservoir in Utinga (Cruz, 1944).

In 1901, the Water Service Directorate responsible for choosing the Utinga area as the main source of supply for Belém was created. For that purpose, an old farm on the site was expropriated, where the springs of Utinga, Catu and Buiussuquara were located (Bordalo, 2006, p 150). At the time, several measures had already taken place to protect Utinga's water bodies, such as the approval of the Statute of the Companhia de Águas do Grão-Pará in 1881. However, the company was expropriated by Decree No. 127/1893, and was later replaced by the Law No. 501/1897 and then Law No. $611 / 1898$ that 
regulated the distribution of water in Belém. The same was carried from five headwaters of the water courses present in the Utinga stream to a circular well used as a reservoir (IMAZON, 2013) .

According to Bordalo (2013, p.149), from 1930 onwards important constructions were made for the use of water sources, such as the capture of the springs of the Catu, Água Preta and Buiussuquara streams, then in 1945 with the signing of the contract with company Byington e Cia, a plan for the remodeling of the water supply services in Belém was drawn up, which were completed in 1968.

In the 1960s, water management in Belém was in charge of the Department of Water and Sewage (created in 1962), however the increase in anthropogenic disturbances was accentuated with the construction of BR 163, accelerating spontaneous occupation to the north of the springs. During the military government the control and execution of the water supply of Belém was in charge of the Companhia de Saneamento do Pará (COSANPA), founded in 1970.

Given this situation, there have been negative environmental consequences in Utinga over the years due to the association of high occupancy rates, mainly in the north, with the lack of public policies.In 1982, the Government of the State of Pará listed the area of the water sources in Belém for its landscape, ecological and tourist complex. That same year, COSANPA hired a company to prepare a "Diagnosis of the Urban Study and Sanitary Protection of the Bologna and Agua Preta Lakes". In that study, it was recommended, for the first time, the creation of an "ecological park on the banks of the reservoir. "

The Government of Pará, through decree No. 3,251 / 1984, instituted an area of 1,598.10 hectares, as a public utility for the purpose of expropriation, which was called "Sanitary Protection Area - Lake Bolonha and Água Preta". Subsequently, the "Special Protection Area for the purpose of preserving the Springs of the Metropolitan Region of Belém" was created, including the hydrographic basins tributary to the reservoirs (Decree No. 3,252 / 1984). In addition, through decree No. 3,521 / 1986, the government instituted that the forests in the area should be permanently preserved.

The first Management Plan for the use of the sanitary protection area was prepared in 1987 by the Development and Administration Company of the Metropolitan Area of Belém (CODEM), in partnership with the Brazilian Agricultural Research Corporation (EMBRAPA), Faculty of Agricultural Sciences of the Pará da Amazônia (FCAP / UFRA), Museu Paraense Emílio Goeldi (MPEG) and Brazilian Institute for Forestry Development (IBDF). One of the proposals elaborated was the need to standardize the occupation around the area.

In this scenario, the Environmental Protection Area of the Water Supply Fountains of Belém (also called APA Belém) arises, the creation of which arose from the need, as detailed in State Decree No. 1551/93, for the protection of the water reservoirs of the Bologna and Water lakes Preta, responsible for supplying $65 \%$ of the population of the metropolitan region of Belém (SECTAM, 2003). APA Belém covers an area of 7500 hectares and involves the municipalities of Belém and Ananindeua, comprising the hydrographic basins of the Bologna and Água Preta lakes and the Guamá River.

According to SNUC, in the APA only the management of the area is limited, not implying expropriation or change of domain, aiming to improve the environmental conditions of a certain area and protect regional ecosystems. In this sense, the APA is defined as:

[...] terrestrial and / or aquatic areas, of viable configuration and size, submitted to different management modalities, which may comprise a wide range of natural, semi-natural, or altered landscapes, with remarkable characteristics and endowed with biotic, aesthetic attributes or cultural that require protection to ensure the well-being of human populations, conserve or improve local ecological conditions or protect landscapes and important natural and cultural attributes (Brasil, 2000).

In the case of Utinga, APA Belém functions as a buffer zone for the PAB (PEUT). The buffer zone was clearly conceptualized, by means of art. 2nd, item XVIII, of Law No. 9,985, of July 18, 2000 as "the surroundings of a conservation 
unit, where human activities are subject to specific rules and restrictions, with the purpose of minimizing the negative impacts on the unit". As highlighted by Gomes (2007), in this area human concentration and the formation of a network of social actors are diversified with the objective of a sustainable project.

Despite the APA Belém being a Conservation Unit for Sustainable Use presented, in its creation decree, among its main objectives, restrictive aspects especially directed at the springs, as shown in the items below:

"Toensure the potability of the water in the springs, through the restoration and maintenance of the environmental quality of the lakes Água Preta and Bologna; promote environmental sanitation and urbanization of occupied areas, including providing for the use of alternative sewage treatment technologies; promote the recovery of degraded areas, including reforestation; preserve the biodiversity represented by the plants, animals and ecosystems of the varzea, igapó and terra terra forests; "(State Decree n $\left.{ }^{\circ} 1551 / 93\right)$.

According to Araújo Júnior (2013), the creation process of APA Belém generated disagreements between the occupants of the Utinga area and the public power due to the way the UC implementation was carried out. For the same author, the period between 1993 and 2003, APA Belém only existed on paper, since the implementation process took place in an arbitrary way, disregarding the presence of resident residents over 30 years. In addition, the lack of consistent environmental management made it possible for the growth of irregular occupation to continue around the urban park, even encroaching on the limits provided for by State Decree 1,552 of May 3, 1993.

Even with territorial control, the irregular occupation of Utinga has become one of the most relevant vectors in the anthropic pressure in the supply sources of Belém, either due to the increase in the demand for treated water or changes in areas close to the Bologna and Água Preta lakes. When talking about occupation of the Park at Utinga, three topics should be highlighted: occupation within the limits of the wall; the invasion of the buffer zone; and the degradation of the Bologna and Agua Preta lakes.

In this sense, the occupation of the land around the $\mathrm{PAB}$, was characterized by congregating essentially urban uses and activities, with the exception of the areas to the south, southeast and northeast (MAPA 1). The territorial portion immediately to the west and north presents Avenida Almirante Barroso and its continuation, BR-316, as the main axis of urban equipment, not only in this area but also in the city of Belém. Residential, industrial uses predominate along this axis. and services.

To the north of the Park the use is predominantly residential, with typologies ranging from middle class and upper middle class residential areas to invasion areas with low class sub-dwellings. The occupation of the area is predominantly horizontal, encompassing the neighborhoods Curió-Utinga, Guanabara, Castanheira and Águas Lindas. In some stretches the residences advance to the headwaters of the lakes Bologna and Água Preta, and in Bologna this situation occurs more intensely (Figure 1). 
Figure 1: Aerial view of Lake Bologna in the PEUT.

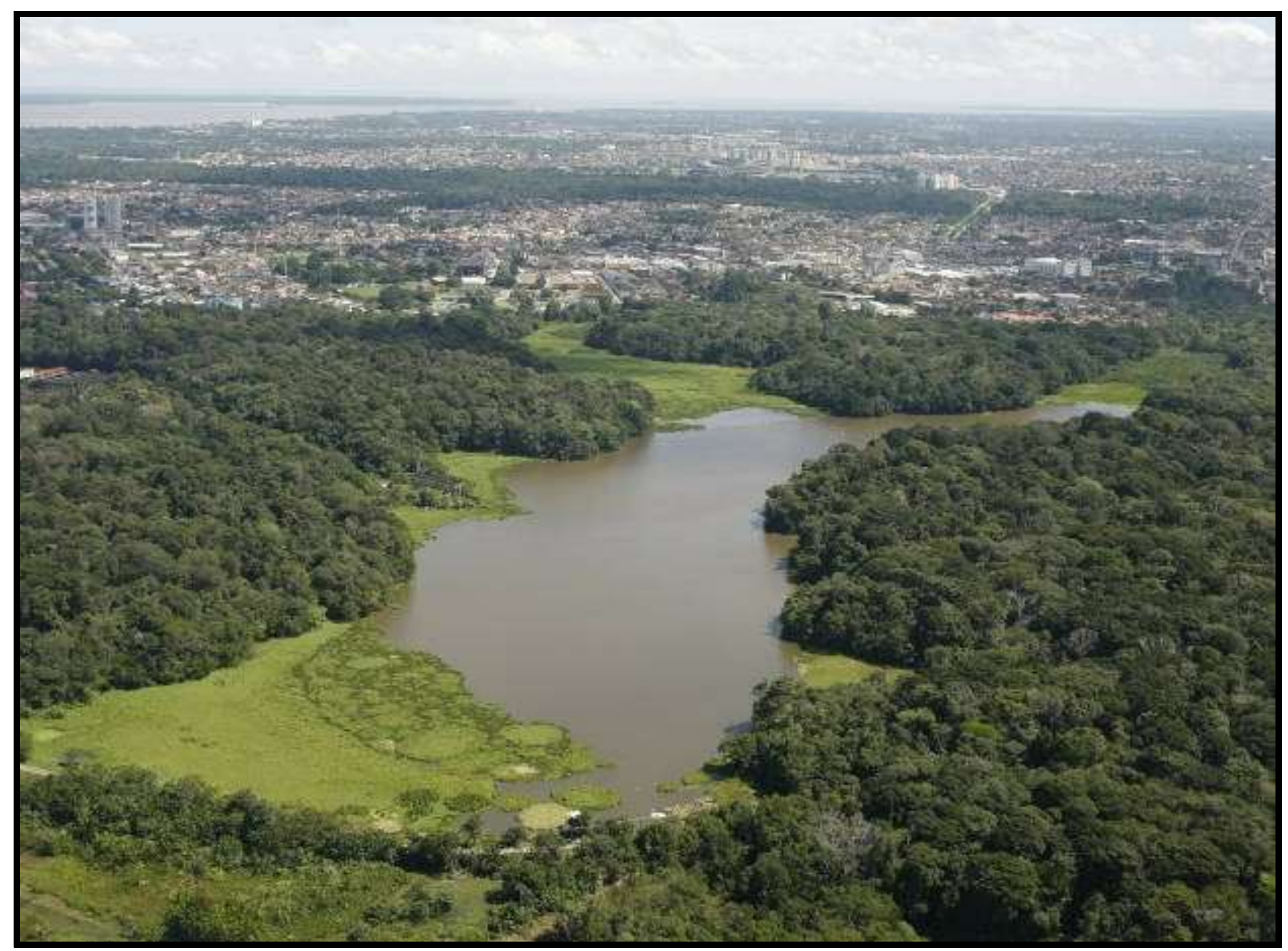

Source: Authors.

Among the invasions to the north, it is worth mentioning an area of sub-dwellings located on the banks of Lake Água Preta, whose domestic sewage is discharged directly into one of the springs that contribute to the formation of the lake. This invasion area, located within the patrimonial limits of COSANPA, had already been the object of expropriation and relocation, and the area was later invaded.Likewise, the source of Lake Bologna also had its banks invaded again after the expropriation of the area.

To the east of the springs, land use is also quite diverse along the neighborhoods of Águas Lindas and Aurá. Areas occupied by sub-dwellings are found, as well as sites, clubs and middle class residences, as well as a kennel and a cemetery. It is worth mentioning in this area the implementation by the public authorities of three horizontal housing estates on the banks of the Águas Lindas Road, which required the deforestation of extensive green areas, the remainder of which are still significant, are found in the surroundings and predominantly to the east and to the east. south of those housing estates.

To the west of the area, between the limits of the urban park and Avenida Almirante Barroso, the use is residential and institutional. Among the agencies installed are SESAN (Belém Municipal Sanitation Secretariat), and Pará Police Department of the Ministry of Agriculture. Castanheira neighborhoods are found in this area. The south of the urban park houses the PEUT buffer zone, in addition to the Food Supply Center of the State of Pará - CEASA / PA, and is part of the Curió-Utinga Neighborhood.

Also in the area surrounding the PEUT area, it is also worth noting for its potential to contaminate lake water, the Aurá sandpaper composting plant and sanitary landfill (closed in August 2014), whose implantation site was located at 1400 
meters from Água Preta lake, at the head of the Aurá river (Figure 2). This river flows into the Guamá River, approximately $250 \mathrm{~m}$ upstream of COSANPA's water intake.

Figure 2: Aurá embankment in the area surrounding the PEUT

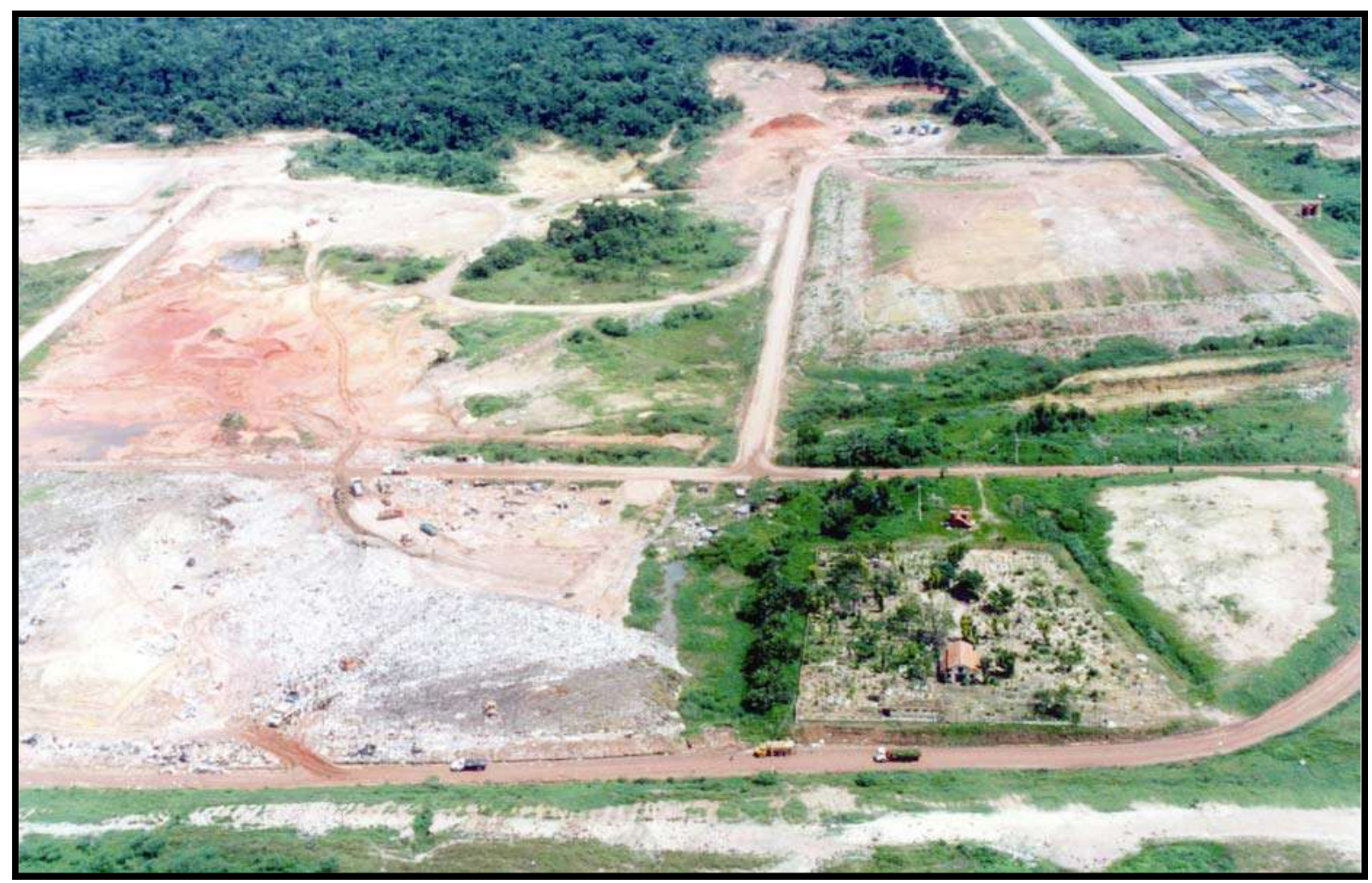

Source: Authors.

Although the Bolonha and Agua Preta Lakes receive the drained water from their basins, which together cover approximately $1,825.20$ ha, the volume is maintained mainly by the waters subtracted from the Guamá River, which are discharged into the Água Preta Lake through a pipeline installed on the banks of the Guamá River, near the mouth of the Aurá River. The purpose of pumping is to supply the "deficit" of water destined for supplying Belém, since the rivers that feed the lakes do not have sufficient flows.

Population growth in the area around Utinga, over the years, has not been accompanied by urban basic sanitation equipment, causing outbreaks of environmental degradation from the deforestation of forests, and water through sewage and garbage that flows into the forests. lakes springs. During the rainy season, the water table, as well as the Aurá River, suffer the possibility of direct contamination by leachate, since its mouth is 200 meters from COSANPA's water intake and pumping pumps in the Guamá River, which supply water. the lakes through the pipeline, putting the city's water sources at risk.

The topographic characteristics of the area, evidenced by the existence of low elevation levels, with easily flooded land, makes the Utinga springs even more vulnerable to the polluting action arising from the leaching of higher lands, the easy transport of domestic effluents, in addition to the strong polluting contribution. from the Aurá landfill. Add the environmental impact caused by seasonality in the dry season and, still, the repression of surface, muddy waters of the Guamá River, which receives strong influences from the penetration of saline waters from the Atlantic and from the contributions of urban contamination. (Júnior \& Costa, 2010). 
The transformations that occurred around the urban park, from the second half of the seventies, also reproduced, within the area of the Utinga springs, which until then, was distinguished by the predominance of institutional and rural land use. Urban appropriation was characterized by alternative forms of housing known regionally as "invasions", in which families occupy and take possession of "empty" public or private urban land, building small wooden houses (or using tarpaulins), waiting for a future expropriation and regulation.

The understanding of the expansion of illegal occupations and the risks that they have come to represent for the Utinga springs are fundamental to explain the creation of APA Belém, in 1993. It is noteworthy that this fact would occur after thirteen years after institutionalization a national level of legal bases on APA (law No. 6,902, of April 27, 1981), but seven years before SNUC (federal law 9,985 / 00).

In this context, the creation and implementation of UCs for the protection of the water sources in Belém has become part of the construction of a sustainable image of the city that is both practical, as well as symbolic, abstract. The process of urban expansion that took place in the city further accentuated socio-environmental problems. In addition, in general, there are structural issues, with a strong presence of informal occupations, garbage accumulation, violence where the level of spatial segregation is articulated. (Vieira \& Pereira 2016, p. 732 ).

Figure 3: COSANPA Treatment Plant within the limits of the PEUT

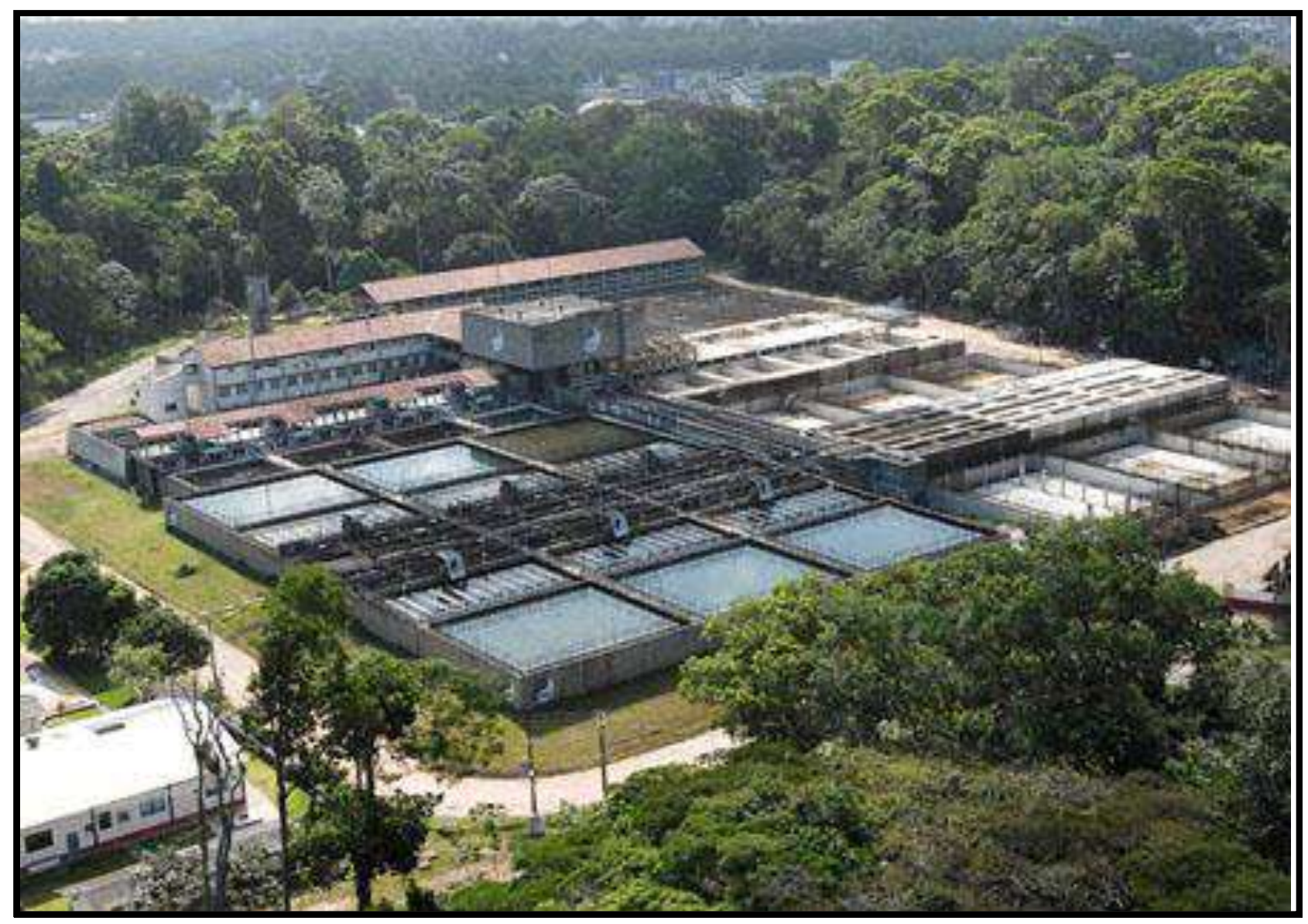

Source: Authors.

With regard to the current use and occupation within the limits of the PEUT area, the following facilities and activities are currently found:

- Pipeline of the Guamá River; RMB Water Treatment Station (ETA); 
- COSANPA offices;

- Institute of Forest Development and Biodiversity of the State of Pará - IDEFLORBio

- Pará Environmental Police Battalion

a) Invasions (residential use) at the headwaters of the lakes and in the extension of Avenida João paulo II

Therefore, the municipality of Belém, like many other Brazilian cities, did not plan its urban growth and the environmental impacts have directly and indirectly affected the preservation of these areas. In the case of PEUT, there is also the issue of recreation space for residents, as well as enabling the development of scientific, cultural, educational and tourist activities. According to Araujo et al (2012) the success of the management of the springs depends on the appropriation of the issue of sustainability, which in turn depends on the achievement of the objectives addressed by the SNUC.

\section{Legal aspects of governance of urban parks in Belém}

Brazilian environmental legislation defines two basic types of green protected areas: those without definition of dimensions and boundaries, such as forests, the sea, caves, mountains; the other type has its dimensions and physical limits defined, are the Conservation Units (UCs): Environmental Parks, Environmental Protection Areas, among others.

The National System of Conservation Unit (SNUC) created by law $n^{\circ} 9.985$ / 2000 as an organized system capable of making the national conservation objectives feasible, where the main focuses are: planning, management and management of the Conservation Units.The SNUC was instituted and approved on June 21, 2000 and sanctioned by the president of the republic of the time Fernando Henrique Cardoso, in order to establish criteria and rules for the creation, implantation and management of the UCs.

SNUC created two separate groups of units: integral protection units and sustainable use units.The first group has the objective of preserving nature, accepting the use of activities that do not cause changes, such as, for example, scientific research and controlled public visitation, thus encompassing certain management categories, the Comprehensive Protection UCs are composed of five different categories, while the UCs for sustainable use, aim to conserve nature with the use of natural resources.

As for the group of full protection units, they are subdivided into: 1) Ecological Station aims to preserve nature and carry out scientific research; 2) The Biological Reserve aims to fully preserve the biota and other natural attributes; 3) Monumento Natural has as its basic objective to preserve rare natural sites, singular or one of great scenic beauty; 4) The Refugio de Vida Silvestre aims to ensure conditions for the existence or reproduction of species; 5) The Environmental Park has as its basic objective the preservation of natural ecosystems.

According to the SNUC / MMA registration data (2017), the following categories predominate taking into account the federal, state and municipal scope in Brazil: Environmental Protection Areas with 307 units (14.6\% of the total of UCs); Parks with 406 units (19.3\%); Forest with 106 units (5\%); Private Reserve of Natural Heritage with 845 units (40.2\%).

In the State of Pará there are currently around 79 Conservation Units (IDELFORBio, 2017), 51 of which are Federal, 3 municipal and 25 UCs at the State level (Table 1). The state UCs are distributed in the territory of 32 municipalities covering approximately $16.94 \%$ of the total area of the State of Pará. 
Table 1: State Conservation Units created in the State of Pará (1989-2016).

\begin{tabular}{|l|l|c|c|}
\hline Unity of & Category & The amount & Area (ha) \\
\hline \multirow{4}{*}{ Comprehensive Protection } & state Park & 4 & $97,219.32$ \\
\cline { 2 - 4 } & Ecological Station & 1 & $4,245,819.11$ \\
\cline { 2 - 4 } & Ecological Reserve & 1 & $1,151,761.95$ \\
\cline { 2 - 4 } & Wildlife Refuge & 3 & $10,740.49$ \\
\hline \multirow{3}{*}{ Sustainable Use } & Environmental Protection area & 8 & $8,266,509.03$ \\
\cline { 2 - 4 } & State Forest & 4 & $7,862,320.87$ \\
\cline { 2 - 4 } & Sustainable Development Reserve & 25 & $95,195.90$ \\
\hline Total & & $21,729,565.61$ \\
\hline
\end{tabular}

Source: IDEFLORBio (2017).

The context of the formation of Conservation Units in the State of Pará begins in 1961, with the creation of the National Forest of Caxiuanã, by the Brazilian Institute for Forestry Development (IBDF), located in the municipalities of Portel, Melgaço, Gurupá and Porto de Moz. During this period, the emergence of National Forests coincides with the start of major mining projects in the eastern Amazon.

Regarding state UCs, the first three UCs created were Environmental Protection Areas, interesting, according to Ribeiro (2010), which were instituted by 3 different legal instruments (Federal Constitution, Law and Decree). The oldest state UC in Pará is APA Marajó, introduced from Art. 13 of the 1989 State Constitution of Pará. It is considered the largest Conservation Unit in the northern region of Brazil, covering the municipalities of Afuá, Anajás, Breves, Cachoeira do Arari, Chaves, Curralinho, Muaná, Ponta de Pedras, Salvaterra, Santa Cruz do Arari, São Sebastião da Boa Vista and Soure.

It is a process of creating an atypical UC and formalized only by one paragraph: "The Marajó Archipelago is considered an environmental protection area in pará, and it must take into account the economic vocation of the region, when making decisions with a view to its development and improving the living conditions of the Marajoara people" (Pará, 1989, art.13, inc.2). However, to date, there have been no legal challenges or other legal aspects that detail the objectives of the UC.

The creation history of the second oldest state UC, APA Algodoal-Maiandeua, also involves a different context. Located in the municipality of Maracanã, APA was created in 1990 through approval by the State Legislative Assembly of a draft law prepared by the Institute of Economic, Social and Environmental Development of Pará (IDESP), at the request of Non-Governmental Organizations (NGOs) who frequented the Island of Algodoal and was already concerned with the conservation of the environment.

The APA for the water supply sources of Belém was constituted by a state decree ( $\left.\mathrm{n}^{\circ} 1.551\right)$ in 1993, together with the PEUT, also conceived by IDESP and whose main objective was to ensure greater protection for the Bologna and Agua Preta Lakes. From this, the state UCs were created through state decrees, due to the consolidation of rules and guidelines suggested by SNUC.

Ribeiro (2010, p.59) understands the process of creating UCs in the state of Pará from three stages: 1) Up to the 1980s, based on existing studies and ratified through field trips; 2) from the structuring of the Executive Secretariat for Technology and Environment (SECTAM) in 1991, which started to assume the competence to create the UCs; 3) with the advent of SNUC, which demanded greater demands for the implementation of UCs.

In addition, the geographical distribution and the time of creation of UCs in the State respond to different political, economic and social contexts specific to each region. In this sense, the creation of these protected areas precedes or coincides 
with the advancement of some kind of anthropic pressure, such as pioneering front, irregular occupation of urban green areas, deterioration of river sources.

The contextualization of the creation of UCs in Pará has another differential, the fact that it belongs to the Amazon biome, which due to the increase in deforestation, pollution, among others, in contrast to the sustainability discourse leveraged mainly by international agencies, put pressure on the public power in institutionalize ecosystem protection. This pressure provided a series of measures to amortize the problem, including the realization of protected areas in the State.

According to Lobato (1988), the methodology for selecting the regions consisted of surveys of studies from institutions such as IBDF, IDESP, SUDAM, among others, to later carry out technical visits to investigate the information. At this time, there were already several proposals for the category and objectives of the UC, according to the same author, the preservationist view prevailed, that is, the predisposition to create fully protected UCs without much concern to reconcile with the local reality, especially in relation to the surrounding residents.

In 2005, with State Law No. 6,745 / 2005, the Ecological-Economic Macrozoning of the State of Pará (MZEE) was prepared, which allocated new conservation areas that were decisive for the territorial division of use and occupation of state UCs. According to Art. 4, it was designated in areas in which 65\% of the total area was destined to protected areas and 35\% was only destined to the expansion of productive activities or the recovery of degraded areas.

Notwithstanding the law that created SECTAM in 1988 (State Law No. 5,457), it was only implemented in 1991 with the incorporation of the technical staff and structure coming from the technical staff coming from the State Department of Public Health SESPA and IDESP. In 1993, SECTAM was restructured, creating the Division of Conservation Units, which was the baseline although timid of the management of state UCs.

In 2007, State law 7,026 changed the name of SECTAM, the State and Environment Secretariat (SEMA) emerged, which now has a new organizational structure. The Directorate for Protected Areas was created, which now deals directly with the issue of creation, implementation and management of UCs, in addition to indigenous and quilombola lands. There was, according to Ribeiro (2010, p.65) a significant quantitative and qualitative increase in relation to planning, since the state UCs started to have a manager and a specific technical team, although in an incipient way.

In 2015, there was a new change in the structure of the State, the state UCs were under the responsibility of IDEFLORBio, taking advantage of the technical staff of the old DIAP, the Directorate for Management and Monitoring of Conservation Units (DGMUC) was created in order to strengthen the management, planning and control of these areas. 
Table 2: Legislation on the Environmental Management of Conservation Units in the urban area of Belém.

\begin{tabular}{|c|c|}
\hline Legislation & Contribution \\
\hline Federal Decree No. 23,793 / 1934 & $\begin{array}{l}\text { Institutes the old forest code, introducing the figure of the Conservation Unit in the } \\
\text { Brazilian context }\end{array}$ \\
\hline Federal Law No. 4,771 / 1965 & Institutes the Forest Code, determining the government to create national parks \\
\hline Federal Law No. 6,938 / 1981 & Institutes the National Environment Policy \\
\hline Federal Constitution 1988 & Determines the establishment of specially protected territorial spaces \\
\hline State Law No. 5,457 / 1988 & Creates SECTAM \\
\hline State Law No. 5,752 / 1993 & Restructures SECTAM and the State Environmental Council (COEMA) \\
\hline State Law No. 5,887 / 1995 & Provides for the State Environmental Policy \\
\hline Federal Law No. 9,985 / 2000 & Creates the National System of Conservation Units \\
\hline State Law No. 6,745 / 2005 & Institutes the Ecological-Economic Macrozonemaneto of the State of Pará \\
\hline Municipal law nº 8,489 2005 & Municipal Environment Policy and the Municipal Environment System (SISEMMA) \\
\hline Federal Decree No. 5,758 / 2006 & Institutes the National Strategic Plan for Protected Areas (PNAD) \\
\hline State Law No. 7,026 / 2007 & Emergence of SEMA replacing SECTAM \\
\hline Law No. 6,963 / 2007 & $\begin{array}{l}\text { Deploys the Pará Forest Development Institute, which in } 2015 \text { takes over the } \\
\text { Management of UCs in Pará }\end{array}$ \\
\hline Law No. 8,655, of June 30, 2008 & $\begin{array}{l}\text { Belém Urban Master Plan and the institution of Space Areas for Environmental } \\
\text { Preservation }\end{array}$ \\
\hline
\end{tabular}

Source: Ribeiro (2010) adapted by the authors.

Under the management of IDEFLORBio, 8 of the 25 state UCs have a Management Plan, which according to SNUC is the "technical document through which, based on the general objectives of a conservation unit, its zoning and the rules that must be established preside over the use of the area and the management of natural resources, including the implementation of the physical structures necessary for the management of the unit" (Article 2, item XVII, of Federal Law No. 9,985 / 2000)

The Management Plan, or Management Plan, was legally instituted in Brazil in 1979, through the National Parks regulation decree (Decree $n^{\circ}$ 84.017), although it was legally expanded in 2000 in the context of the creation of SNUC (2000) . One of the most relevant aspects of this Decree was the institution, in its fifth article, of the Management Plan defined as "a dynamic project that, using ecological planning techniques, determines the zoning of a National Park, characterizing each of its zones and proposing their physical development, according to their purposes" (Brazil 1979).

The objective was to adapt and guide the ecological management of national parks, hitherto mostly created only on paper, pointing out the need to carry out zoning as a basis for the ordering and management of protected territory (Medeiros \& Pereira, 2011, p.2) .The establishment of Management Plans in environmental parks, however, was not an original initiative either. It is a planning practice for park management initiated in the North American tradition and was widely disseminated in Brazil since the 1960s.

RMB has seven urban parks in operation (Table 3), three of which are private, where the ecological function is below the objective of commercially exploring the landscape. 
Table 3: Urban parks in the Metropolitan Region of Belém.

\begin{tabular}{|c|c|c|c|}
\hline Name & Responsibility & Normative & Year \\
\hline Utinga State Park (former PAB) & state & Decree $n^{\circ} 1330$ & 2008 \\
\hline Belém Ecological Park (Gunner Vingren) & Municipal & Law 7539 & 1991 \\
\hline Mosqueiro Ecological Park & Municipal & Decree No. 26138 & 1993 \\
\hline Ananindeua Environmental Park & Municipal & Law 2,472 & 2011 \\
\hline Igarapés Park & Particular & & 1986 \\
\hline Amazon Crocodile Safari Park & Particular & & 1989 \\
\hline Gunma Ecological Park & Particular & & 1996 \\
\hline
\end{tabular}

Source: Brito, (2009) adapted by the authors.

Belém Ecological Park Gunnar Vingren[6] (PEGV) is a fragment of forest located between the neighborhoods of Valde-Cans and Marambaia, with an area of 35 hectares. PEGV according to municipal law 7539/1991 aims to preserve, maintain and restore the green area. However, the creation of the park is linked to the social movements of the residents who demanded the protection of the primary forest, which started to suffer invasion and depredation from the end of the 1980s (Cardoso, 2015).

The management of PEGV is carried out by the Municipal Environment Department (SEMMA) of Belém and has an active management board with 20 chairs. However, even with the advances in the legal instruments engendered by the Municipal Environment Policy, of the Municipal Environment System (SISEMMA), paradoxically, the governance limitations (human and financial resources) end up weakening the spaces of participation, consequently the urban park was not appropriate as actions for the collective good and this maintained the possibilities of illegal occupation of the area.

The Ananindeua-PA Municipal Park and the Mosqueiro Island Park belong to the RMB expansion area.However, these are places that are not recognized by residents, who do not see their ecological and leisure potential due to the lack of amore significant use, since many refer to these areas as isolated spaces. (Araujo et al, 2012). The lack of a Management Plan $(\mathrm{PM})$ is more significant than the existing problems, making it impossible, therefore, to have an adequate planning for its use, in addition to the lack of information regarding its physical, biological and social characteristics.

Thus, the first management plan in the urban parks of Belém was the PM of the Belém Environmental Park (PAB) of 1994, which was prepared by SECTAM, however the diagnoses were largely outdated, which compromised the planning of the public space. In addition, Costa (2006) noted that less than 35\% of the activities provided for in the PM were carried out in the period from 1994 to 2006. It should also be noted that the document was prepared before Law No. 9,985 / 2000, thus, in the conceptions of SNUC.

In addition, due care was not taken with the buffer zone of the urban park, an area that aims to regulate the use of land in the surrounding area, thus ensuring the protection of the resources present within the UC.The fact is that this buffer zone was not delimited by the 1994 PM, thus making the limits of the PAB even more fragile.If we consider that the park is located within a sustainable use UC (APA in the Metropolitan Region of Belém) and neighboring another fully protected UC (REVIS Metrópole da Amazônia) and that this should serve as an ecological corridor, it is clear that inefficiency of these legal instruments.(Costa, 2006).

However, the institution of SNUC, in 2000, effectively brings a consolidation of the Management Plan as a central tool of the management process for all UC categories (Brasil, 2000). Its Article 27 established that "all conservation units must 
have a management plan" and defined the scope and deadlines. Despite the mandatory nature established by lawNo. 9,985 / 2000, the preparation and implementation of management plans in UCs in Brazil were far from being a consolidated reality.

The efficiency in the implementation of the Management Plan depends, in part, on the ability of managers and their teams to carry out and execute what was conceived, as well as on the ability to overcome an often complex sequence of stages in the process. In the State of Pará, according to the Methodological Roadmap for the elaboration of management plans for the State Conservation Units of Pará (SEMA, 2009).

According to Parise (2010), although the elaboration of the script is a significant advance in the planning and implementation of the document, these methodological scripts have a common deficiency regarding the lack of an integrative methodology for the management programs (Unit management; knowledge; protection resources; management; public use; and recovery). The roadmap foresees as an integrating instance only to hold technical meetings and planning workshops.

Although most environmental plans are theoretically based on integrating proposals with a high degree of interdisciplinarity, in practice the result has been a sum of segmented studies, without an actual interaction, without presenting an integrative scale of decision making. (Parise 2010, p.31)

With the evolution of legal management instruments, it was realized that the preservation of protected areas is linked to facing environmental issues that go beyond the "conservation territory". Gradually, the figure of the buffer zone, of the management council, among others, appears, involving the anthropized spaces of the surroundings in the administration of the integral protection UC.

The buffer zone of an urban park, for example, legally imposes restrictions on the surrounding residents in relation to activities and works that may directly or indirectly interfere with the preservation function. According to Santos (2008, p.75) the intention of the buffer zone is to hinder the edge effects, which in the urban context implies in particular the negative impacts of irregular land occupations in the vicinity of the green area. On the other hand, it seeks to create a population density pattern according to the UC category.

Regarding the management council, it is a direct element of UC management, it can be consultative or deliberative, in the case of PEUT, the management council is consultative, composed of IDEFLORBio, SEMAS, Municipal Environment Secretariat, COSANPA, BPA, Federal University of Pará, EMBRAPA among others. Some of the council's objectives are to diagnose and mediate conflicts, expand knowledge about the park, discuss uses and occupation in the surroundings, and approve the UC Management Plan according to the particularities of the area.

The PEUT Management Plan, prepared by the Institute of Man and the Environment of the Amazon (IMAZON), was ratified at the meeting on October 24, 2013. The objectives mentioned in the final document (PARÁ, 2013) to consolidate the conservation territory in the first 5-year cycle are:

$\checkmark$ Protect RMB's water supply sources;

$\checkmark$ Promote and organize the public use of the area;

$\checkmark$ Implement the physical management infrastructure and standards for public use;

$\checkmark$ Assign appropriate technical staff to demand public use;

$\checkmark$ Encourage, promote and disseminate to the RMB society research that fills the knowledge gaps about UC, in order to subsidize the next management cycle;

$\checkmark$ Potentialize and involve the communities that live in the surroundings with environmental education and public use activities

It is noticed that the emphasis is on the function of protecting the springs and the public use of the urban park, the idea is to take advantage of the PEUT's potential to provide environmental leisure, tourism and education services in favor of the 
main scope of conservation. water supply structure of RMB. In this way, at least in the actions mentioned in this first cycle of the PM, it does not prioritize the ecosystem of the urban park as a whole, because of that the zoning of the PEUT (MAPA 3) presents low intervention areas, which means a high priority for preservation management, only around, mainly, the Agua Preta Lake.

The organization and strategies of these actions proposed by the PEUT PM are specified and divided into 7 management programs: 1) Unit Management;2) Generation of knowledge; 3) Protection of natural resources; 4) Management of natural resources;5) Public use;6) Valuing communities;7) Management effectiveness. (Pará, 2013)

The Unit Management program is directly linked to management effectiveness, focusing on the control of administrative and financial processes to list elements for implementing the management plan.Thus, the installation of the physical structure of the management organ (IDEFLORBio) in the park area, with equipment and technicians present in loco, favors the monitoring and identification of problems.However, the political and economic issue also directly interferes with the guidelines of these two programs.

The purpose of knowledge generation, on the other hand, is to subsidize research on natural resources (water, soils, forests and fauna) to guide and fill the gaps in PEUT's environmental monitoring. In turn, the protection of natural resources is a program aimed at raising awareness among residents and visitors of the park, mainly with actions of environmental education. Meanwhile, the management of Christmas resources is concerned with the recovery of degraded environments, which in the case of PEUT is related to actions aimed at the quality of the water that supplies the city.

The purpose of public use is to see possibilities for leisure activities, ecotourism and education in the park, and to convert these ecosystem services into monetary resources. Despite the PEUT not allowing human presence, the community appreciation program works with the policy of strengthening the bonds of the surrounding residents with the features proposed for the urban park. This is a controversial issue since the main conflicts pointed out in the final document are precisely linked to the anthropic pressure exerted by these communities, irregular occupation of the headwaters of the lakes, dumping of garbage, illegal hunting, etc.

In this sense, according to Cardoso et al (2015, p.81), urban governance involves several variables and different powers that require a broad debate on sustainability in the city of Belém. In 2005, the municipal public power instituted the Municipal Environment Policy and the Municipal Environment System (Law No. 8,489), contributing with a guiding instrument for municipal environmental management. One of the main advances of this law was the emergence of the Municipal Environment Fund (FMMA) with the purpose of financing plans, programs, projects and activities, of an executive nature or of scientific and technological research, aiming at the rational and sustained use of natural resources (Belém, 2005). The institutionalization of this policy represented an advance in the legal aspects pertaining to the city's green areas.

Subsequently, with the enactment of the Urban Master Plan (PDU) in 2008, the municipal environment policy was systematized, integrating it directly with the city, in the "search to promote the adequacy of the actions of the public power in the development of its socioeconomic activities. with environmental balance "(Belém, 2008). In effect, the PDU came to guide the public environmental policies of Belém, which even started to consider the specificities. Thus, urban parks were conceptualized as a Special Area for the Preservation of Environmental Heritage, which aims to preserve the city's green areas.

However, the environmental governance model developed from the construction of the various legal aspects in Belém, still comes up against the issue of strengthening collective actions for environmental management. Cardoso et al. (2015, p.87) show that as the institutional spaces of dialogues are formalized, paradoxically, the residents of the surroundings lose their active form of claim in the interaction with government agents and they start to control actions. As a result, conflicts are accentuated by diverging interests and the ineffectiveness of public power to manage public spaces, namely urban parks. 


\section{Conflicts and interests in the configuration of the PEUT}

The implantation of a UC is a measure involved in a lot of controversy, which divides opinions, mainly in the case of a category with greater use restriction, as is the case of urban parks. It is observed that the establishment of legally protected areas through territorial control, by themselves, does not ensure preservation, involving different interests and views, in addition to determining a change in the local dynamics.

According to Santos (2010) the institutionalization of PEUT triggered a socio-environmental issue, since in the area, where there were already several spontaneous occupations, there was an intensification of this invasion process by residents who do not recognize the importance of relating in a sustainable way with the environment. The contrast between the right to housing and the right to the environment is evident in the discussion between removing the families that live in the surroundings, with the aim of fully protecting the PEUT; or, promote land tenure regularization, based on criteria that allow the realization of the right to housing with the least possible environmental and social impact.

However, this process of irregular occupation in the vicinity of the PEUT is not limited to the low-income population. According to Silva et al (2014) this movement is carried out by human groups from different social classes, in fact, it can be seen in this area around the PEUT middle-class residential complexes, country headquarters of private leisure organizations of the elite of Belém, public offices, luxury houses, poor slums and hovels, humble daycare centers and very expensive schools, in addition to areas occupied by family farmers. Therefore, the deterioration of the border areas of the water sources in Belém is not an isolated product for a social group.

In 2007, there were about 1,300 residents within the PEUT, of which 1270 were relocated by the State Environment Secretariat (SEMA) during the agency's management period (2007-2015). However, there is an aggravation of the situation of families that are still inside the park, especially due to the lack of infrastructure, such as violence and deficiencies in the water supply network, energy and basic sanitation, which lead them to use alternatives, such as sewage and open-air garbage.

In 2012, there were 153 people, distributed in 66 families (IBGE, 2010). In addition to these, there are reports of other residences that are being built recently, mainly due to the growth and division of families. Most were located in the neighborhoods of Castanheira and Guanabara, to the north. In the south there was only one resident family. The area inhabited by these people accounted for less than $0.05 \%$ of the total area of the PEUT. 
Figure 4: Occupation within the PEUT (Águas Lindas).

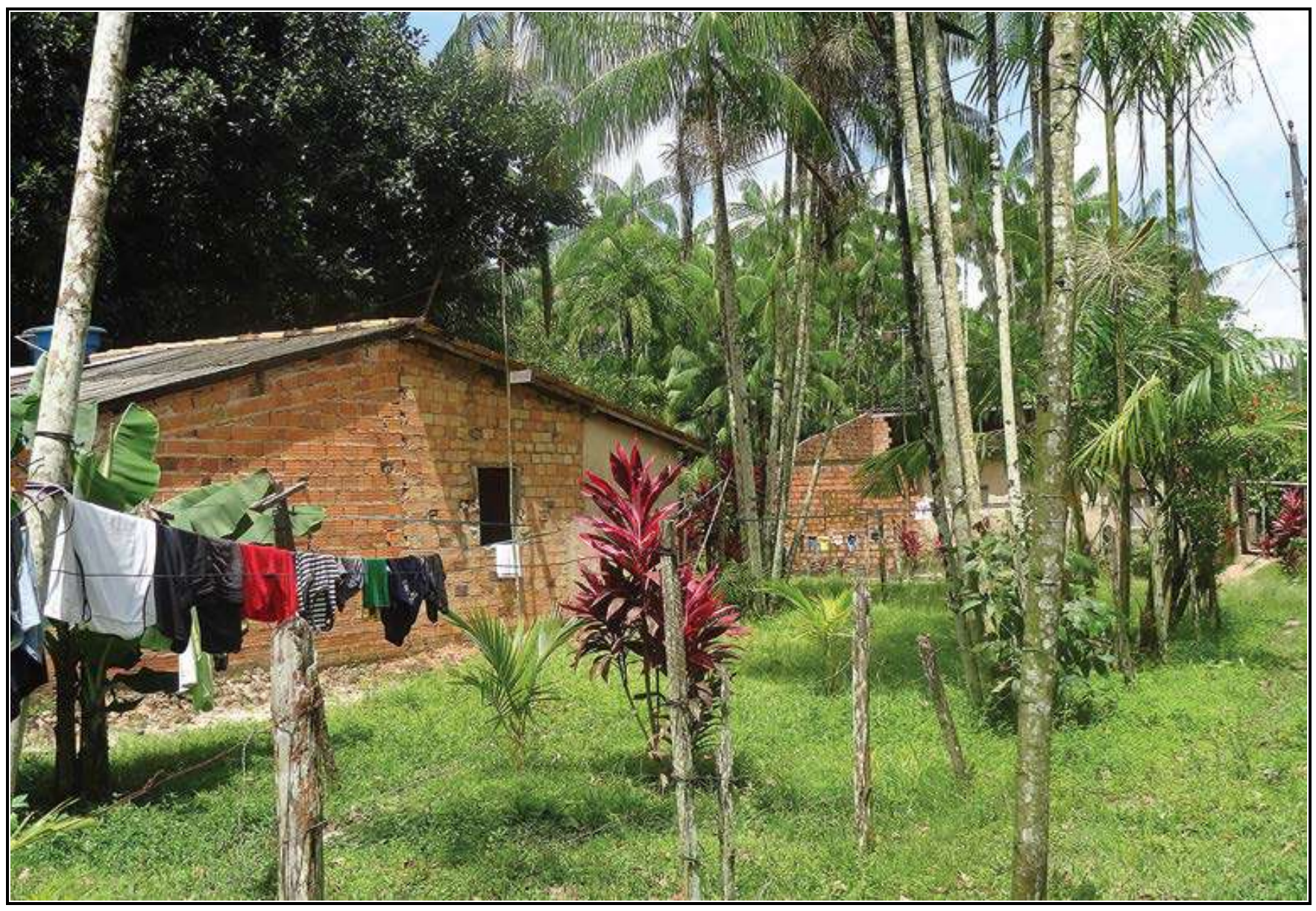

Source: Authors.

The dynamics of the occupation of the green space is closely linked to the history and demographic and urban expansion of the municipalities of Belém and Ananindeua. According to reports by residents, the occupation of the area that is now known as "Utinga" (which at the time belonged to COSANPA) started around 1978, due to the request for occupation and construction of residences by employees of the state company (Pará, 2013, p .174).

No traditional population was found in the park, but residents from other municipalities in Pará and states, such as Maranhão. Thus, the establishment of residences within the limits of the park occurred due to the expansion of the existing streets and villages in the surroundings (continuation of the streets, etc.), migration of people, expansion of families and the RMB. However, the resident of the south of the park is a former COSANPA employee who took care of this area of the park (former COSANPA Club) near Lake Água Preta (Pará, 2013, p.174).

According to Pará, 2013, most (52\%) of these families have lived in the same place for more than twenty years: $21 \%$ of them have a period of stay between twenty and thirty years; $18 \%$ live in the place between thirty and one and forty years; and $13 \%$ have been there for over forty years. Only $17 \%$ of families have lived in the park area for less than five years. Thus, there is a controversial land issue in the area, since even though these irregular occupations are in urban spaces that are environmentally protected, they generate certain rights for residents.

In fact, the history and demographic and urban expansion of the municipalities of Belém and Ananindeua ended up causing some families to enter the area of the Utinga park. In theory, there could not be any form of human occupation that would harm the environment, however the reality does not match what occurs in practice, where in most cities in Brazil there is no urban planning and the population unduly occupies areas protected by legislation. 
Table 4: Population density in the interior of the Utinga State Park in 2012.

\begin{tabular}{|l|l|l|l|}
\hline PEUT location & Neighborhood & $\mathrm{N}^{\circ}$ Families & $\mathrm{N}^{\text {o }}$ people \\
\hline North & Guanabara; Chestnut tree & 26 & 78 \\
& & 21 & 63 \\
\hline South & Bullfinch-Utinga & 1 & 3 \\
\hline East & Beautiful waters & 18 & 54 \\
\hline Total & 66 & 153 \\
\hline
\end{tabular}

Source: Pará (2013).

In the immediate surroundings of the PEUT, that is, an area physically closer to the limits of the UC, there were 39,165 residents in 10,605 households, according to data from the IBGE census sectors (2010). In the area up to 1 kilometer away from the park's boundaries, 128,676 people lived in 35,107 households in the neighborhoods of Guanabara, Castanheira, Águas Lindas and Curió-Utinga.

The Castanheira neighborhood was created by a 1995 or 1996 municipal law. Its name is due to the existence of a chestnut tree where Shopping Castanheira is today. From then on, the process of occupation of the neighborhood began to put pressure on the limits of the PEUT, which only decreased after the management of the area decided to limit it to prevent further invasions. In turn, the Guanabara neighborhood emerged when one of the first residents compared the lakes Bologna and Água Preta with the Guanabara Bay, in the city of Rio de Janeiro. The origin of the neighborhood is estimated to be more than 70 years old, the same emancipation period as Ananindeua.

The Curió-Utinga neighborhood, which was between the avenues Almirante Barroso and João Paulo II, was initially part of the Marco neighborhood, and was like "Curió" because it is a green area close to the forest with many birds of this species. As this area was not yet inhabited, it drew the attention of some people, who started to build their houses there. Therefore, occupations in the area surrounding the park are relatively old (Pará, 2013, p.174).

In this context, several surveys were carried out in the area surrounding the PEUT, evaluating the perception of residents about the environmental policy of the city represented by the management of the UC for full protection. Alves et al (2015) carried out a research in the stretch between Rua Moça Bonita until Santa Isabel Passage, which has been suffering socio-environmental impacts due to the anthropic action resulting from human occupation and, since the year 2011, work has been taking place to prolong the Avenida João Paulo II as an alternative route for vehicle traffic in Belém.

As for the residents' knowledge about the PEUT, the work of Alves et al (2015) shows that the majority, 23 (57.7\%) did not manifest any kind of understanding about it, while 17 (43.3\%) of them cited attributes, such as: the protection of lakes, forests and animals, the conservation of a green space and leisure area. Thus, it is evident the lack of information by a large part of the interviewees about what an integral protection unit is and the importance it represents in the sustainable practice of the city and which aims at the valorization and protection of environmental resources.

Despite this, the residents see advantages of living in the vicinity of the PEUT, the main ones were related, according to $31(77.5 \%)$ residents, to clean air; in sequence, 18 (45.0\%) mentioned tranquility; 16 (40.0\%), birdsong; and $13(32.5 \%)$ the scenic beauty of the place. On the other hand, the disadvantages consisted mainly of the high rate of robberies, according to 27 (67.5\%) interviewees; $26(65.0 \%)$ associated the area with drug trafficking, $22(55.0 \%)$ with insecurity and $15(37.5 \%)$ emphasized the proliferation of insects that, consequently, invade homes, draws attention to the fact that more than $10 \%$ cited the lack of access to the urban park, although it is a close and public area. 
In this regard, urban parks are seen as green areas and spaces for leisure and contemplation, they contribute to improving the quality of life of the local population, but they are prone to numerous socio-environmental problems (Guedes et al., 2013), such as those found in present research, which cause discontent to the people involved. (Alves et al, 2015, p.356)

Another interesting point of this work refers to the involvement of the residents interviewed in the activities offered to the public by the Management Body of the UC at the time - the State Secretariat for the Environment and Sustainability (SEMAS), $30(75.0 \%)$ residents do not participate in these activities. actions, while $10(25.0 \%)$ have already experienced community environmental education practices. This minority also emphasized: hunting and fishing and the spa, although they are developed in an irregular and unauthorized manner.

However, in the case of individual dissatisfactions, of a socio-environmental nature, in the household perimeter and, concomitantly, in the urban park, the most mentioned were: the improper dumping of household waste in the area with 31 (34.0\%) citations; followed by 16 (17.6\%) regarding water pollution, mainly for consumption; 14 (15.4\%) on illegal hunting and fishing within the PEUT, which tend to decrease biodiversity; the lack of water for daily utilities and also deforestation with $11(12.1 \%)$ mentions each. Thus, Alves et al. concludes that despite the superficial knowledge of the ecological function, and discontent with some management actions, the manifestations of community environmental practices should be encouraged in the area.

Baia Jr and Guimarães (2004) carried out a survey in the Moça Bonita community, around the PEUT, in which most of the interviewees present little or no knowledge about the urban park, although they have already visited it informally, without any involvement in environmental education programs. Regarding the level of frequency of visits, it was expressed by the interviewees themselves that they do not do it anymore, because this practice was prohibited and supervised by the Environmental Police Battalion (BPA).

On the other hand, when questioning residents about the importance of the urban park. The responses demonstrate that the population has a minimal understanding of the importance of the green area both for collective well-being and for the preservation of natural resources:

Table 5: List of justifications about the importance of PEUT conservation.

\begin{tabular}{|l|c|}
\hline ANSWERS & FREQUENCY \\
It is an important leisure space & 0.24 \\
Ensures the survival of the animals that live in the area & 0.17 \\
Protects Bologna and Agua Preta lakes & 0.13 \\
It benefits the residents of the area: it improves the environment and purifies the air. & 0.13 \\
Allows contact with nature & 0.1 \\
It is an important space for the preservation of nature & 0.1 \\
Enables knowledge of nature & 0.07 \\
Ensures the preservation of vegetation & 0.03 \\
Provides a well-being for the residents of the surroundings & 0.03 \\
\hline
\end{tabular}

Source Baia Jr (2004). 
Figure 5: Occupation near the distribution pipes of piped water (Curió-Utinga).

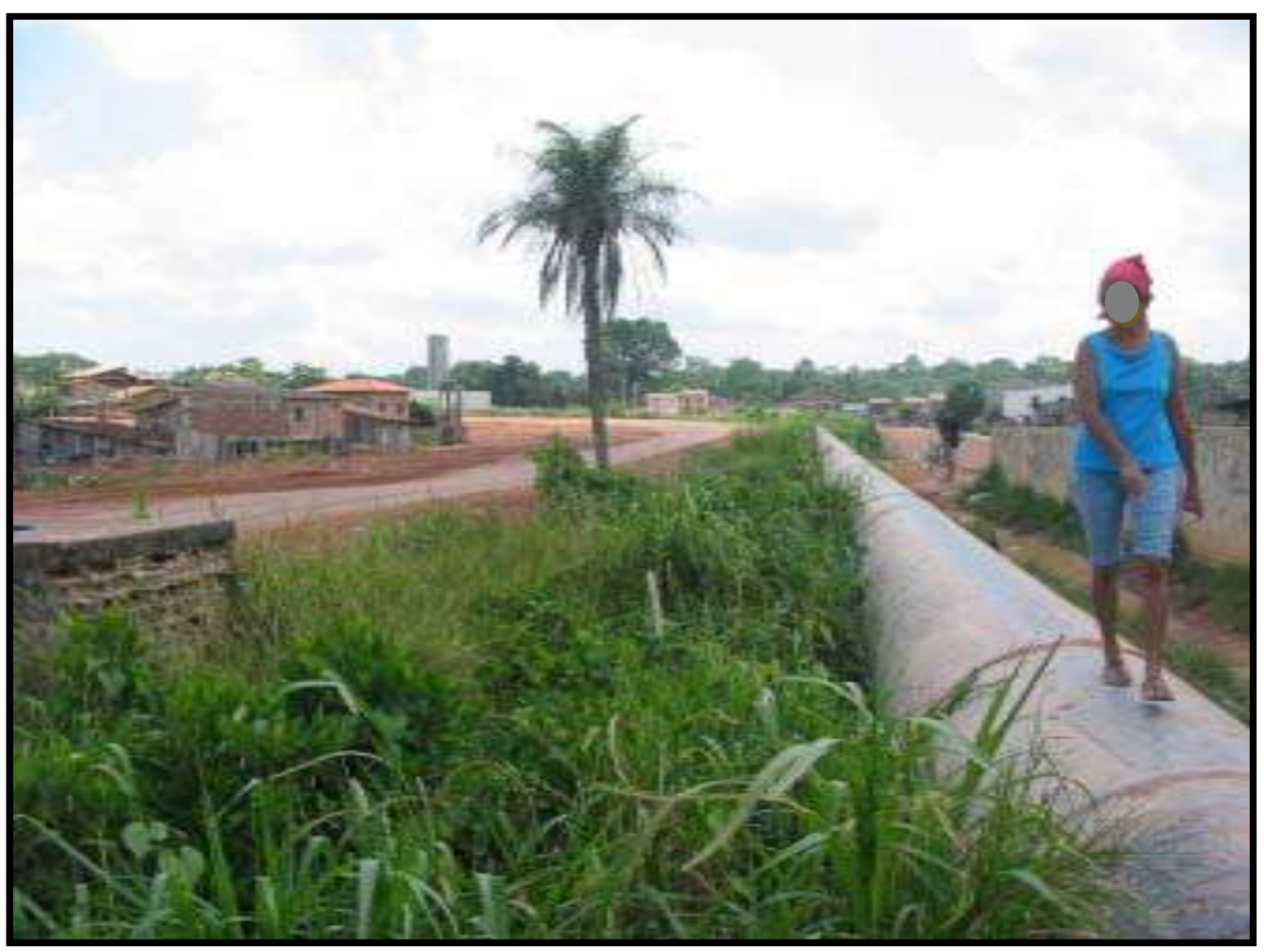

Source: Authors.

Still in the same study area, Santos (2010) states that in fact there is an environmental perception on the part of the residents, and that several of them, although they have a low level of education, do have the cognitive ability to become aware of the preservation of the green area urban. However, in evaluative terms the collective movements unfold towards conflict or territorial resistance, since they occupy the area irregularly.

Paradoxically, the institution of the "conservation territory" contrasts historically with the "culture[8]" of the residents of the surroundings of Utinga, causing degradation to the city's supply network (Baia JR and Guimarâes, 2004). According to a survey on the water quality of the water sources in Belém, 21 sewage discharge points were identified at the headwaters of the lakes (SEMA, 2013: 180).

For Santos (2010), this lack of perception of the UC by the residents of the surroundings of Utinga points to the construction of a "territory of resistance" and, at the same time, of coexistence, based on cognition and actions to raise awareness of the importance of environmental sustainability. in the city. However, the same action spills over into movements to challenge current control, such surrounding communities are increasingly organizing themselves into neighborhood associations that are struggling to ensure improvements in their stay in the area.

In addition, according to research carried out by Leray (2010) there are 32 families that are within the limits of the PEUT, which definitely confronts the categorization of full protection of the SNUC (federal law 9.985 / 00), most of these occupants show dissatisfaction with the management of the park, denouncing the indiscriminate dumping of garbage, hunting and fishing among other environmental irregularities. The same study also indicates that the PEUT is considered a risk area for these families, especially at night, because robberies and even deaths occur inside. 
Figure 6: Garbage accumulated on one of the PEUT tracks.

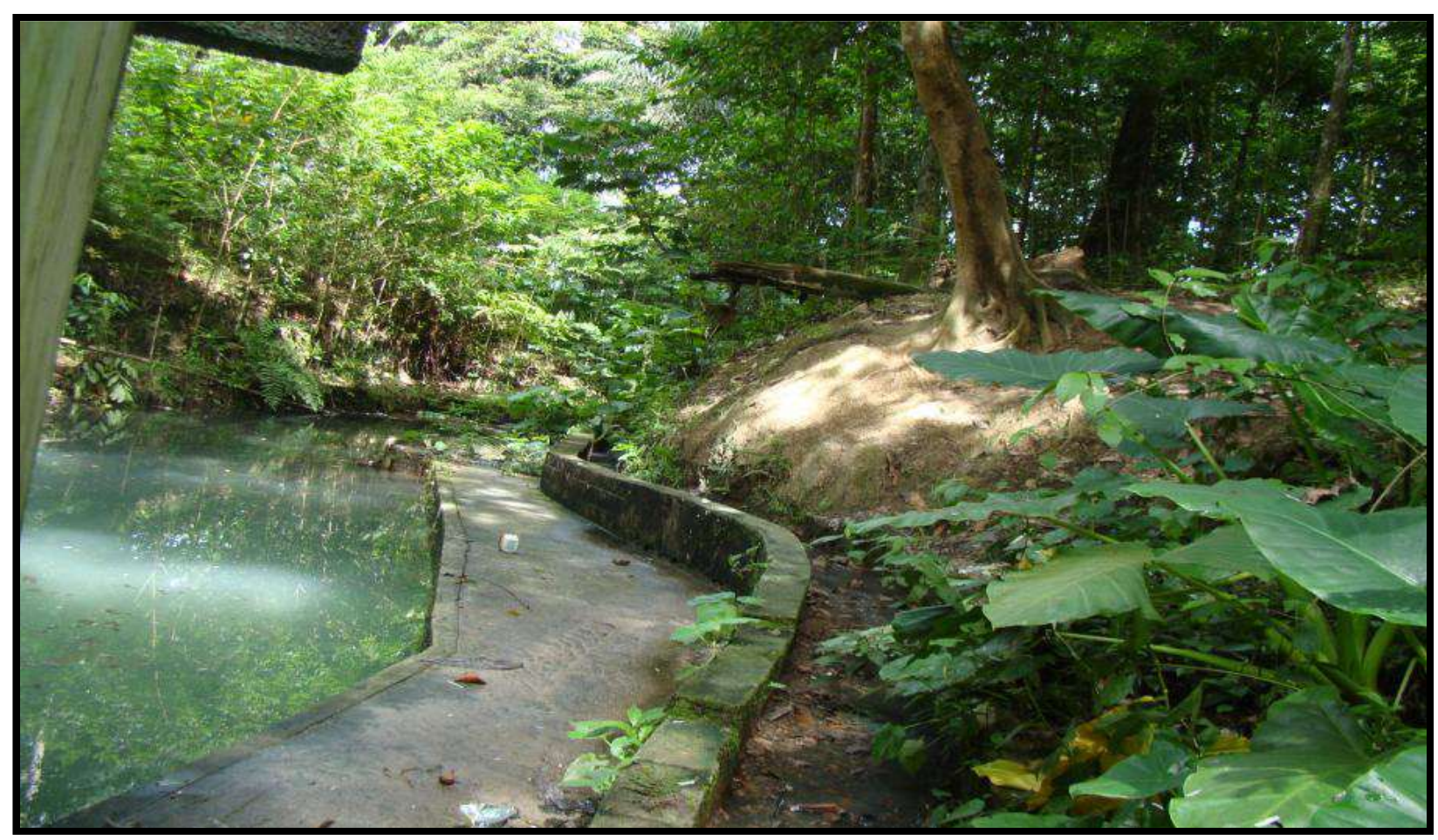

Source: Authors.

In this context, several authors such as Ferreira et al (2012) Amaral et all (2009) and Luz and Rodrigues (2014) defend emergency management actions in the "conservation territory", such as the creation of other protection areas in the urban space of Belém, and the increase in control and use mechanisms. The point is that the city's forest fragments have problems in relation to the degree of isolation in relation to the urban environment, demographic pressure and governance limitations.

According to Brito (2009, p.68) in the view of PEUT managers[9] the infrastructure to develop environmental education, leisure and inspection activities has been reduced since its origins in 1993. Political issues and a lack of funds have been reported as the main obstacles to environmental management, but understanding with the community is seen as something positive by the manager, mainly the implementation of environmental education projects, seminars, training courses for teachers in the surrounding schools, in an attempt to preserve the PEUT.

In turn Correia (2014) points out that visiting activities are excessive and free in the PEUT, which have contributed greatly to the deterioration of the environment, the author defends a rationalization of the visitation process of the urban park, through the reduction and control of entrances and exits and the creation of revitalized and signposted ecological trails, in which passersby would have the company of specialized guides to avoid actions that harm biodiversity

Thus, public policies in Utinga necessarily need the collaboration of all, since without the proper environmental education of local residents and society in general, PEUT does not play its role of integral protection. Baia Junior et al (2004) questions the action of indiscriminate release of wild animals, as reported by the authors from 1994 to 2003, 2472 animals were introduced, distributed in birds (65.4\%), reptiles (27.7\%) and mammals (6.9\%), many of the loose species were not registered, which alters the balance of the ecosystem. Currently, there are no systematic records of animals released in the PEUT area, according to information obtained from GEFAU / DIFISC / SEMAS and BPA.

According to Araújo Júnior (2015) the expansion of the urban occupation of the PEUT reflects in the reduction of protection against surface erosion (run off), which leads to an increase in the silting up of the margins and headwaters of the 
springs. In addition, the aforementioned author draws attention to the high occurrence of macrophytes in Lake Bologna, which shows the concentration of nutrients conducive to their proliferation, which compromise the water supply network, since the decomposition of organic matter causes deoxygenation of water., making it less suitable for human intake.

Bordalo (2006), in turn, makes a negative assessment of the management of the hydrographic basins in the municipality of Belém, especially the Utinga springs. In his conclusion, he reinforces that the legal measures to protect the surface waters that supply the city of Belém, which includes the consolidation of the PEUT, were not effective in their objective. According to the author's words, the "bureaucratic model" of management and population growth are the determining factors, since the instruments created by the government in a centralized and hierarchical way were not enough to reduce the impacts of anthropism in the park.

Anyway, following the line of reasoning of Moura and Costa (2009: 294) the biggest challenge for the environmental management of a public green space in this sense is the implementation of activities for leisure, research, ecotourism and environmental education, considering the real potential of these areas, converging to the interests of residents, both those in the area and visitors who seek contact with nature. This implies a greater assessment of the potential of the urban park, the effective participation of all the actors involved, as well as integrated studies on environmental vulnerability in view of the (un) ordering of the demographic occupation in the area.

\section{Final Considerations}

In the case of PEUT, it was noticed that despite potentially having favorable conditions such as housing the city's water sources, having a large part of its surroundings occupied by public institutions, having a relatively small area, having the headquarters of the managing body (IDEFLORBio) and of control (BPA) within its area, the urban park has negative numbers in terms of preservation and control over the use of the area. Given this perspective, the problem raised here had as its central scope precisely the assessment of the environmental management of the PEUT through the crossing of the variables of the ecological, social and educational functions.

Thus, the aim was to provide a perspective on the theme proposed here: the challenges for the environmental management of an environmental park in the space of urban expansion, often disordered and contradictory. Justifying the present work from the perception of the different uses, functions and occupations of the space, at first it was essential to know what was the historical context of the creation of the UC, to study the relations of the surrounding community with the park, to check the view of the current managers and old ones, make an analysis of the Management Plan and other legal instruments, thus verifying what was thought and what the PEUT actually means for the city.

On the other hand, the questioning of both the social actors involved and scientists about the real contribution of urban parks to territorial ordering and environmental regularization in spaces of pressure for land use and occupation, as is the case in the city of Belém, is recurrent. The housing policies of the municipal government that encouraged the creation of housing estates in the area surrounding the PEUT clearly demonstrate these contradictions in the government's commitment to the "conservation territory".

Therefore, the great challenge of environmental management often arises from this "fragility" of the public power in applying sustainable policies capable of disciplining the uses allowed in the area covered by its territory. For Milano (2012: 23) depending on the context in which the UC is inserted, there may be an even greater degree of complexity. The author also recalls that the city's resistance and social function are factors that can increase territorial conflict. 


\section{References}

Albernaz, A. L. M. (2014). Biodiversidade e unidades de conservação na Amazônia brasileira. In: Viera, Ima Célia G, Toledo, P. M., Junior, R. A. O. Ambiente e sociedade na Amazônia uma abordagem interdisciplinar. Garamond. pp.315-340.

Alves, R., Santos, L. M., Araújo, A., Santos, M. R., Pontes, A. (2015). Aspectos socioambientais e participativos da população no entorno do Parque Estadual do Utinga, Pará. Enciclopédia biosfera, Centro Científico Conhecer - Goiânia, 11

Araujo Júnior, A. C. (2015). Indicadores de qualidade ambiental no lago Bolonha, Parque Estadual do Utinga Belém do Pará. Boletim Gaúcho de Geografia, 42, 276-299.

Baía Júnior, P. \& Guimarães, D. (2004). Parque Ambiental de Belém: um estudo da conservação da fauna silvestre local e a interação desta atividade com a comunidade do entorno. Revista Científica da UFPA. http://www.ufpa.br/revistaic Vol 4.

Bordalo, C. (2006). O Desafio das Águas numa Metrópole Amazônida. Uma reflexão das Políticas de Proteção dos Mananciais da Região Metropolitana de Belém - PA (1984-2004). NAEA/UFPA. Belém. p 335. Tese de Doutorado.

Brito, S. K. M. (2009). Parque Estadual do Utinga (PA): Uma gestão ambiental participativa. Dissertação (Mestrado em gestão de recursos naturais e desenvolvimento local na Amazônia) - Núlceo de Meio Ambiente - UFPA, Belém.

Cabral, Cleiton L. (2014). Geografia da "área protegida": uma abordagem sobre os efeitos da expansão urbana na qualidade de vida da APA metropolitana de belém-pa (1994-2009). Papers do naea $\mathrm{n}^{\circ} 326$.

Cardoso, S. L. (2012). Subsídios para gestão ambiental nos Parques urbanos o caso do Parque ecologico do município de Belem. Dissertação (Mestrado em gestão de recursos naturais e desenvolvimento local na Amazônia) - Núlceo de Meio Ambiente - UFPA.

Cardoso, T. M.; Monteiro, F. F.; Venturieri, A.; Campos, G. S. (2009). Análise multitemporal da Área de Proteção Ambiental de Belém e Parque Ambiental de Belém. Anais XIV Simpósio Brasileiro de Sensoriamento Remoto, Natal, Brasil, 25-30 abril, INPE, p. 1283-1290. https://ainfo.cnptia.embrapa.br/digital/bitstream/item/94115/1/1283-1290.pdf.

Correia, B. (2014). Trilha do Bolonha: análise da capacidade de carga turística como Ferramenta de desenvolvimento turístico e uso racional de Espaços públicos naturais em área urbana. V Congresso Brasileiro de Gestão Ambiental Belo Horizonte/MG

Costa, A. L. S. (2006). Efetividade de manejo de duas Unidades de Conservação de proteção Integral no Estado do Pará. Disseratação Escola Superior de Agricultura Luiz de Queiroz, Piracicaba.

Costa, M. J. S. (2015). Uso de indicadores ambientais na avaliação da qualidade de áreas de proteção ambiental: estudo de caso do Parque Estadual do Utinga - Belém (PA). Dissertação apresentada ao programa de Mestrado em Desenvolvimento e Meio Ambiente Urbano da Universidade da Amazônia. Belém.

Bahia, V. E., Fenzl, N., Leal, L. R. B., Morales, G. P., Luíz, J. G. (2011). Caracterização hidrogeoquímica das águas subterrâneas na área de abrangência do reservatório de abastecimento público do Utinga - Belém (PA). Águas Subterrâneas, 25, 43-56.

Gorayeb, A. L. (2012). Monitoramento da Efetividade de Gestão das Unidades de Conservação do Estado do Pará - Parque Estadual do Utinga e Áreas de Proteção Ambiental da Região Metropolitana de Belém, como ferramenta de implementação da gestão integrada destas áreas. Dissertação. Mestrado profissional em gestão de áreas protegidas na Amazônia. Instituto nacional de pesquisas da Amazônia - INPA.

Leray, Ester Barbosa. (2010). Impactos sócio-ambientais: um estudo sobre a preservação ambiental do Parque Estadual do Utinga - Belém/Pa. Monografia. Especialização em Gestão Ambiental e Desenvolvimento Sustentável na Amazônia. Faculdade Ipiranga.

Melo, M. J. C. M. (2009). Área de proteção ambiental - APA: movimento social urbano e educação ambiental em Belém. IV Jornada internacional de politicas públicas-Unama. http://www.joinpp.ufma.br/jornadas/joinppIV/eixos/8_agricultura/movimento-social-urbano-em-area-de-protecao-ambiental.pdf

Ribeiro, J. (2010). Área de Proteção Ambiental da Iha do Combu. Desafios de implantação e de gestão de uma Unidade de Conservação. Belém, NUMA. 155 f. Dissertação (Mestrado) - Universidade Federal do Pará, Núcleo de Meio Ambiente, Belém, 2010. Programa de Pós-Graduação em Gestão dos Recursos Naturais e Desenvolvimento Local na Amazônia.

Rocha, E. B. (2011). Problemática sócio-ambiental à luz do sensoriamento remoto: o caso da comunidade jardim nova vida na área de proteção ambiental metropolitana do município de Belém, Estado do Pará. Dissertação (Mestrado em gestão de recursos naturais e desenvolvimento local na Amazônia) - Núlceo de Meio Ambiente - UFPA, Belém.

Rojas, J. P. H. (2017). Dinâimica da cobertura vegetal e o uso do solo em unidades de proteção integral: o Parque Estadual Utinga no Estado do ParaBrasil. PPGEO, 2017. 75 f. Dissertação (Mestrado) - Universidade Federal do Pará, Instituto de Filosofia e Ciências Humanas, Belém. Programa de PósGraduação em Geografia. http://repositorio.ufpa.br/jspui/handle/2011/9466

Santos, T. (2010). A percepção ambiental dos moradores do entorno do Parque Estadual do Utinga. Estudo de caso: A ocupação da rua moça bonita (Guanabara-Ananindeua-Pará). Dissertação de mestrado. PPGCA/UNITAU.

Silva, L. M. (2014). Qualidade ambiental das águas dos mananciais do Utinga e dos rios Guamá e Aurá, Belém, Pará. Dissertação apresentada como requisito parcial para obtenção do título de mestre em Ciências Ambientais no Programa de Pós Graduação em Ciências Ambientais. Universidade do Estado do Pará.

Silva, A. H. \& Dias, V. A. (2002). Elementos de informação no entorno da APA-Belém: análise através da percepção de estudantes pesquisadores. Revista Traços, 5, 41-50 http://revistas.unama.br/index.php/revistatracos/article/view/878/431 
Research, Society and Development, v. 10, n. 9, e28110915440, 2021

(CC BY 4.0) | ISSN 2525-3409 | DOI: http://dx.doi.org/10.33448/rsd-v10i9.15440

Souza, C. B. G.; Campos, A. S.; Sousa, F. B. B.; Santos, A. M. A.; Carvalho, G. P. (2020). O uso de indicadores ambientais na avaliação de unidades de conservação: o caso do Parque Estadual do Utinga em Belém/PA (PEUT). Nature and Conservation, 13, 86-94. http://doi.org/10.6008/CBPC23182881.2020.001.0010

Vasconcelos, V. M \& Souza, C. (2011). Caracterização dos parâmetros de qualidade da água do manancial Utinga, Belém, PA, Brasil. Revista Ambiente \& Água - An Interdisciplinary Journal of Applied Science: 6 